\title{
POSAMEZNIKOVO ODLOČANJE ZA ZAPOSLITEV V POGODBENI REZERVI SLOVENSKE VOJSKE
}

\author{
INDIVIDUAL'S CHOICE TO SEEK EMPLOYMENT \\ IN THE SLOVENIAN ARMED FORCES CONTRACT \\ RESERVE
}

Povzetek Ob prehodu na poklicno popolnjevanje je proučevanje posameznikovega odločanja za različne oblike vojaške službe postalo zelo pomembno, saj so se oborožene sile soočile s konkurenčnimi iskalci delovne sile, s katerimi pogosto glede na ugodnosti, ki jih lahko ponudijo, in glede na posebnosti in zahtevnost dela težko tekmujejo. $\mathrm{V}$ primerjavi s proučevanjem pridobivanja in zadrževanja kadra za stalno sestavo oboroženih sil so analize, ki se ukvarjajo s pridobivanjem in zadrževanjem kadra za rezervno sestavo, predvsem zaradi pomanjkanja podatkov, veliko redkejše. S socio-psihološkim proučevanjem smo tako pri pogodbenih pripadnikih rezerve sestave Slovenske vojske preverili, kateri so ključni dejavniki odločanja za zaposlitev v pogodbeni rezervi. Pri tem smo prišli do ugotovitve, da imajo poleg ekonomskih spodbud pri odločitvah posameznikov za zaposlitev v pogodbeni rezervi pomembno vlogo tudi dejavniki, ki izhajajo iz osebnega odnosa posameznika do zaposlitve v pogodbeni rezervi, normativnih pritiskov oziroma podpore, deskriptivnih norm in ocene samoučinkovitosti, pa tudi številni drugi, bolj oddaljeni dejavniki, kot sta demografija in informiranost.

Ključne Vojaška rezerva, zaposlitev v oboroženih silah, ekonomski in socio-psihološki besede dejavniki, Slovenska vojska.

Abstract During the transition to professional armed forces, the study of individual's motives for various forms of military service became increasingly important. The professional armed forces have been confronted with competitive employers, who are often hard to compete with, considering the benefits they can offer as well as the characteristics and complexity of the work. Compared to the studies regarding the recruitment and retention of permanent military personnel, the analysis of the recruitment and retention of reserve military staff are much rarer, mainly due to the lack of data. With the help of socio-psychological framework applied to Slovenian Armed Forces contract reserve members, we thus determine the key factors triggering decisions for 
the employment in the contract military reserve. In doing so, we came to the conclusion that, in addition to the economic stimulation, the factors contributing to the individuals' decision to seek employment in the contract reserve are the following: factors resulting from individual's personal attitude towards the employment in the military contract reserve, normative pressures or support, descriptive norms, selfefficacy assessment, and many other more remote factors, such as demographics and information.

Key words Military reserve, employment in armed forces, economic and socio-psychological factors, Slovenian Armed Forces.

Uvod Izkušnje kažejo, da se sodobne industrijsko razvite družbe pogosto srečujejo s težavami pri popolnjevanju oboroženih sil. Pri tem so rezervne sile navadno najpomembnejša alternativna oblika zagotavljanja poklicne popolnjenosti oboroženih sil, ${ }^{1}$ zato se raziskave ukvarjajo tudi s pridobivanjem in vzdrževanjem pogodbene rezervne sestave. Rostker in Shishko (1976) sta razvila teorijo, da odločitev posameznika za vstop v rezervno sestavo temelji na izbiri med prostim časom in dodatnim prihodkom oziroma na dejavnikih, ki drugače vplivajo na posameznikovo odločitev za honorarno delo. Temu pritrjuje tudi Burrightetal s sodelavci (1978), ki so med posamezniki, ki se odločajo za vstop v rezervno sestavo, ugotovili sorazmerno veliko plačno neprilagodljivost. Brinkerhoff in Grissmer (1986) prva opozorita na pomembne razlike med honorarnim delom in službo v rezervni sestavi, Mehay (1991) pa empirično dokazuje, da posameznikova odločitev za zaposlitev v rezervni sestavi kljub močnemu vplivu njegovega dohodkovnega statusa ter lokalnih zaposlitvenih razmer ni podobna odločitvi za honorarno delo. Buddin (1993) je s proučevanjem novega nabornega programa $» 2+2+4$ « ugotovil, da so ugodnosti dodatnega izobraževanja povezane s posameznikovo odločitvijo za službo v rezervni sestavi. Thomas in Kocher (1993) pa sta ugotovila, da posameznike v rezervni sestavi zadržujejo dejavniki, ki opredeljujejo tudi odločitev za primarno, polno zaposlitev. Posledično se je tudi pri proučevanju odločitve posameznika za vstop v rezervno sestavo začel tako kot pri posameznikovem odločanju za zaposlitev v oboroženih silah uporabljati socio-psihološki okvir proučevanja (Bachman, 1998; Fishbein, 2000; Sackett, 2004), ki omogoča vključitev tako ekonomskega dojemanja koristi kot tudi okoljskih dejavnikov, ki jih poudarjajo ekonomski modeli poklicne izbire.

Ministrstvo za obrambo Republike Slovenije je leta 2001 v svoje dolgoročne načrte razvoja zapisalo prehod na poklicno popolnjevanje Slovenske vojske, ki se v vseh poznejših dokumentih opredeljuje kot poklicna vojska, dopolnjena s pogodbeno rezervo. Stalna in pogodbena sestava sta tako postali dve dopolnjujoči se sestavini Slovenske vojske, za kateri je treba izvajati primerno politiko zaposlovanja. V članku

Kljub dejstvu, da so rezervisti znatno cenejši od pripadnikov stalne sestave, in temu, da številne države uporabljajo rezervne enote za izvajanje nalog, ki nakazujejo na morebitno možnost zamenjave stalnih enot $z$ rezervnimi, je na splošno premalo znano o učinkovitosti rezervnih sil in času, potrebnem, da te sile dosežejo bojno pripravljenost (Sandler, 1992, str. 162, 163). 
bomo zato najprej na podlagi različnih teoretičnih izhodišč odločanja za zaposlitev v oboroženih silah, nato pa še s podrobnejšo analizo rezultatov empirične raziskave Upravljanje človeških virov v Slovenski vojski: pogodbena rezerva, družine in konec vojaške službe, poskušali odgovoriti na raziskovalno vprašanje, kateri so ključni - ne le ekonomski, temveč tudi sociološki in psihološki - dejavniki, ki med pogodbenimi pripadniki določajo interes za zaposlitev v rezervni sestavi Slovenske vojske.

Temeljni pristop pri proučevanju odločanja za zaposlitev v oboroženih silah bo temeljil na združitvi različnih ekonomskih in socio-psiholoških teorij posameznikovega odločanja. Delovanje dejavnikov, ki vplivajo na interes za zaposlitev v pogodbeni rezervi oboroženih sil, je mogoče proučiti samo s kombinacijo različnih teoretičnih in empiričnih raziskovalnih metod, zato bomo pri proučevanju že uveljavljenih teorij in novejših ugotovitev ter spoznanj na tem področju uporabili analizo vsebine pisnih virov ter prikaz vlog in nalog v analizo vključenih dejavnikov, ki vplivajo na zaposlovanje v oboroženih silah. V empiričnem delu članka pa bomo z analizo empiričnih podatkov in statistik, pridobljenih iz rezultatov raziskav Upravljanje človeških virov $v$ Slovenski vojski: pogodbena rezerva, družine in konec vojaške službe, predstavili podatke o interesu pogodbenih pripadnikov za nadaljnjo zaposlitev v rezervni sestavi Slovenske vojske.

\section{ODLOČANJE ZA ZAPOSLITEV V OBOROŽENIH SILAH}

Teorije o odločanju za zaposlitev v oboroženih silah so raznolike in del različnih znanstvenih področij. Ekonomske teorije odločanja za zaposlitev v oboroženih silah tako poudarjajo predvsem dejavnike na makro ravni, usmerjene na sredstva za pridobivanje in zadrževanje človeških virov v oboroženih silah, razmere v gospodarstvu, plače ter možnosti zaposlitve v vojaškem in civilnem sektorju gospodarstva. Socio-psihološke teorije odločanja za zaposlitev v oboroženih silah pa po drugi strani bolj poudarjajo dejavnike na mikro ravni, usmerjene na lastnosti posameznika in posameznikove odločitve, njegove vrednote, odnos in socialne pritiske.

Izhajajoč iz ekonomske teorije izbire posamezniki povezujejo celotno korist s posamezno možnostjo izbire in nato sledijo tisti, ki je zanje najbolj koristna (Schwartz, 2002). Tako je Oi (1967) zasnoval model poklicne izbire, v katerem se posameznik o zaposlitvi v oboroženih silah odloči na podlagi razlike med nizom vojaških plačil in plačil za najboljšo alternativno civilno zaposlitev. Altman in Fechter (1967) sta model dopolnila še z vključitvijo stopnje brezposelnosti, ki neposredno vpliva na višino plačil v civilnem sektorju. Nadaljnja nadgradnja modela poklicne izbire pa je upoštevala tudi dejstvo, da se lahko zgodi, čeprav je niz vojaških plačil enak nizu civilnih, da posameznik pri zaposlitvi v oborožene sile ni indiferenten, saj obstaja možnost, da ima vsak nekakšno "»nagnjenost do vojaške službe «²

\footnotetext{
Zaradi posebne narave dela v oboroženih silah je razumljivo, da imajo značilnosti takšne službe, kot so npr. neudobje in nevarnost, stroga disciplina, premestitev po vsej državi ali celo zunaj nje, ločitev od družine, pomembno, če že ne glavno vlogo pri posameznikovi odločitvi o zaposlitvi v oboroženih silah (Kennedy, 1975, str. 106).
} 
(Fisher, 1969; Altman, 1971). Ker oblikovani model poklicne izbire ni omogočal reševanja resničnih težav, s katerimi so se pri zagotavljanju poklicne vojaške delovne sile srečevale države, so ekonomske raziskave o zaposlovanju v oboroženih silah začele upoštevati še elemente institucionalnega okolja, med katerimi sta še posebej pomembna učinka politike novačenja (Polich, 1986; Daula, 1985; Berner, 1993) in izobraževalnih ugodnosti (Gilroy, 1990; Horn, 1985; Hosek, 1989).

$\mathrm{Na}$ drugi strani pa so na socio-psihološko proučevanje odločanja za zaposlitev v oboroženih silah v preteklosti najmočneje vplivale te teorije obnašanja: model zdravstvenih prepričanj (healthbelief model), ki trdi, da je verjetnost, da se bo posameznik obnašal na določen način, odvisna od dveh dejavnikov - posameznika mora neposredno ogrožati nek zaznan izid in verjeti mora, da koristi presegajo stroške določenega dejanja (Becker, 1974; Rosenstock, 1994); teorija razumnega delovanja (theory of reasonedaction), ki opredeljuje, da je izvajanje ali neizvajanje danega obnašanja posameznika določeno predvsem z močjo njegovega namena, da se vede na določen način, hkrati pa ta teorija upošteva, da na posameznika vplivajo tudi osebni odnosi, ki so funkcija prepričanj, da bo dano vedenje privedlo do določenega izida, in subjektivne norme, ki so funkcija normativnih prepričanj in motivacij, skladnih s tem, kaj posameznik v resnici želi narediti (Fishbein, 1975; Fishbein, 1991); družbeno kognitivna teorija (social cognitive theory), ki zagovarja, da obstajata dva dejavnika, ki najpomembneje vplivata na vsako obnašanje posameznika - posameznik mora imeti v odnosu do določenega obnašanja občutek samoučinkovitosti in biti mora spodbujen k določenemu obnašanju (Bandura, 1977). Koncept namenov za zaposlitev v oboroženih silah tako v grobem sestavlja »interes za zaposlitev«, dejavnik, ki je pogosto uporabljen v raziskavah o pridobivanju in zadrževanju človeških virov v oboroženih silah (Bachman, 1998; Fishbein, 2000; Sackett, 2004). Vendar pa se interes za zaposlitev v oboroženih silah ne spremeni vedno v resnično obnašanje. $\mathrm{Na}$ to, ali se bo posameznikov interes za zaposlitev v oboroženih silah pokazal tudi v njegovem obnašanju, namreč vplivata še dve skupini oddaljenih dejavnikov. Eno sestavljajo okoljski dejavniki, ki spodbujajo ali ovirajo posameznika pri uresničitvi njegovega zanimanja, ${ }^{3} \mathrm{v}$ drugi pa so tisti dejavniki, ki neposredno vplivajo na to, ali se interes sploh lahko spremeni v obnašanje. ${ }^{4}$

Takšen socio-psihološki okvir proučevanja omogoča tako vključitev ekonomskega dojemanja koristi v obliki plačil in drugih nedenarnih ugodnosti, povezanih $\mathrm{z}$ izbiro, kot tudi vključitev okoljskih dejavnikov, ki jih poudarjajo ekonomski modeli poklicne izbire, zato ga je mogoče nadgraditi v celosten model odločanja za zaposlitev v oboroženih silah, ki vključuje tako racionalnost kot čustva. Tak model odločanja za zaposlitev v oboroženih silah tako predvideva, da na posameznikov interes, da se zaposli v oboroženih silah, vplivajo trije neposredni dejavniki: osebni odnos, normativni pritisk oziroma podpora in percepcija samoučinkovitost (slika 1).

\footnotetext{
Okoljski dejavniki so na primer oddaljenost in dostopnost centrov za novačenje ter obseg in vrste aktivnosti pri novačenju (Sackett, 2004, str. 19).

4 Mednje tako spadajo strokovne kvalifikacije posameznika ter njegove lastnosti, znanje in zmožnosti za zaposlitev v oboroženih silah (Sackett, 2004, str. 20).
} 
Slika 1: Socio-

psihološki okvir

odločanja za

zaposlitev v

oboroženih silah
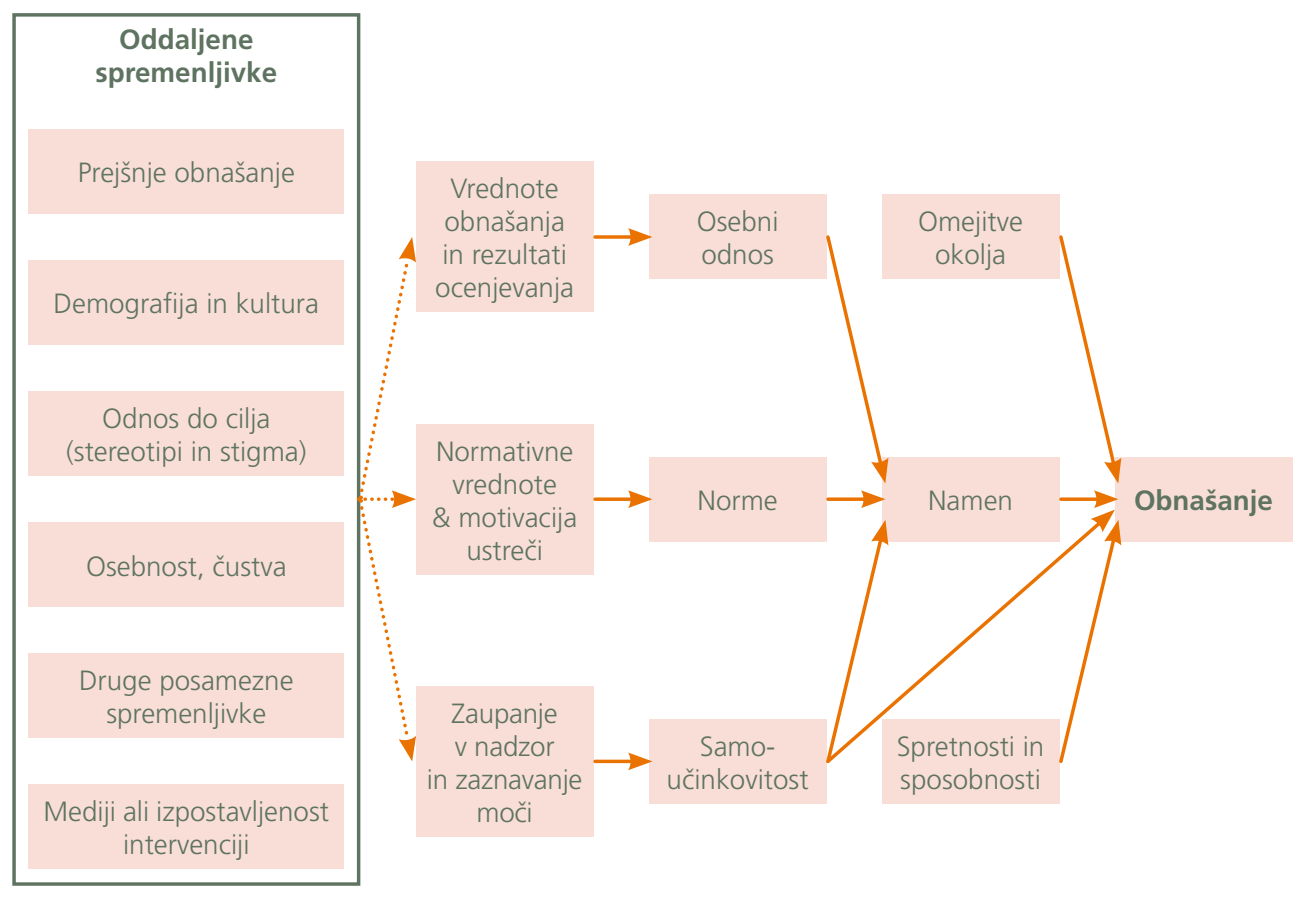

Osebni odnos do vojaške službe sestavljajo ugodni ali neugodni občutki posameznika do zaposlitve v oboroženih silah. Pri tem je posameznikov odnos do zaposlitve v oboroženih silah funkcija njegovih vrednot in rezultat ocen, povezanih s temi vrednotami (Fishbein, 1975; Ajzen, 1980; Andreson, 1996). Posamezniki torej zaznavajo nekatere koristi in slabosti zaposlitve $\mathrm{v}$ oboroženih silah. To zaznavanje se deli na dva dela. Prvi del so pričakovanja, ki se nanašajo na to, s kakšno gotovostjo posameznik misli, da se bodo zgodile koristi ali slabosti, če se bo odločil za eno izmed možnosti (Hastie, 2001), drugi del tega zaznavanja pa je izid ocenjevanja. Nanaša se na to, kako pozitivno ali negativno posameznik zaznava koristi in slabosti. Tako bosta za vsako posledico, potencialno povezano z vojaško službo, vedenjsko prepričanje (subjektivna verjetnost ali pričakovanje) in izid ocenjevanja. Splošni interes za zaposlitev v oboroženih silah je tako funkcija raznolikih pričakovanj in vrednot oziroma natančneje, subjektivne verjetnosti, da bo zaposlitev v oboroženih silah vodila do nekih posledic, ter dejstva, kako pozitivno ali negativno se te posledice zaznavajo.

Drugi dejavnik, ki vpliva na interes posameznika za zaposlitev v oboroženih silah, je normativni pritisk na posameznika oziroma podpora posamezniku. Mnogi namreč pri odločitvah poleg osebnega odnosa upoštevajo tudi to, kaj počno ljudje, ki so zanje pomembni, in kaj zanje mislijo, da bi morali delati. Normativni vpliv na posameznika praviloma oblikujeta dva tipa norm - prepovedne in deskriptivne. Prepovedne se nanašajo na zaznavanje tega, kaj ljudje, ki so posamezniku pomembni, menijo o njegovi zaposlitvi v oboroženih silah (Cialdini, 2003). Ker so si mnenja teh ljudi 
lahko zelo nasprotujoča, so prepovedne norme funkcija subjektivne moči mnenj za posameznika pomembnih oseb (Bakken, 2002). Zaradi tega nekateri teoretiki trdijo, da je pomembno upoštevati tudi posameznikovo motivacijo, da se podredi določeni pomembni osebi (Fishbein, 1975). Deskriptivne norme pa se nanašajo na zaznavanje tega, koliko posameznikovih vrstnikov kaže interes za zaposlitev v oboroženih silah (Borsari, 2003; Cialdini, 2003). Nanašajo se na to, koliko vrstnikov sledi možnosti zaposlitve v oboroženih silah. Ker za različne skupine obstajajo tudi različne stopnje zanimanja, je celotna stopnja zanimanja za zaposlitev v oboroženih silah funkcija vseh teh posebnih stopenj. Pri tem pa socio-psihološka literatura opozarja na zelo zapleteno delovanje na osnovnih stopnjah zanimanja, včasih namreč višja stopnja vodi $\mathrm{k}$ povečanju vedenjskega namena, spet drugič $\mathrm{k}$ temu vodi nižja stopnja.

Tretji dejavnik, ki neposredno vpliva na interes za zaposlitev v oboroženih silah, pa je percepcija samoučinkovitosti. Posameznik se namreč kljub pozitivnemu osebnemu odnosu do zaposlitve v oboroženih silah in podpori njemu pomembnih oseb pri tem ne bo niti poskusil v njih zaposliti, če sam ni prepričan, da je sposoben za to (Bandura, 1994). Neposredno torej na interes za zaposlitev v oboroženih silah vpliva tudi obseg, do katerega posameznik meni, da se je sposoben uspešno zaposliti v oboroženih silah glede na trud, ki ga je v to vložil (Ajzen, 1991). Temeljne determinante celostne ocene samoučinkovitosti so zaznavanje ovir, ki preprečujejo zaposlovanje v oboroženih silah, in sodba posameznika o zmožnosti (ali dojemanju moči), da te ovire premaga. Posameznik je lahko negotov glede svojih zmožnosti, da prebrodi to oviro, poleg tega pa lahko različne ovire tudi različno zaznava. Celotno vrednotenje samoučinkovitosti je tako funkcija različnih dojemanj, ali je ovire mogoče preseči (Bandura, 1994).

Čeprav navedene skupine dejavnikov najbolj neposredno opredeljujejo interes za zaposlitev v oboroženih silah, pa na to vplivajo še številni drugi dejavniki. Njihov vpliv je bolj »oddaljen« v smislu, da so njihovi vplivi na obnašanje posameznika posredni ali pa se kažejo v predstavljenih neposrednih dejavnikih. Teorije obnašanja opredeljuje pet splošnih skupin oddaljenih dejavnikov, ki lahko vplivajo na odločitev o zaposlitvi v oboroženih silah in jih je treba upoštevati (Sackett, 2004, str. 25):

- demografske in socialne značilnosti (starost, izobrazba, spol, socialni in ekonomski status, zaposlitveni status, etnična pripadnost),

- odnos do cilja (stereotipi, povezani s pripadniki oboroženih sil, socialne stigme, povezane z vojaško službo),

- osebnost, razpoloženje in čustva (nagnjenost k iskanju senzacij, pozitivno razpoloženje, čustveni odzivi na vojaško službo),

- različne druge posameznikove lastnosti (patriotizem, družbena angažiranost, nagnjenost k tveganju),

- medijska in posredna izpostavljenost (izpostavljenost pozitivnim ali negativnim slikam oboroženih sil v medijih).

Ekonomske teorije odločanja za zaposlitev v oboroženih silah pa poudarjajo predvsem oddaljeno vlogo tistih, ki novačijo (preference častnikov za novačenje, načini, spodbude), in gospodarskih razmer v družbi. 


\section{INTERES ZA ZAPOSLITEV V POGODBENI REZERVI SLOVENSKE VOJSKE}

Analizo odločitev posameznikov za zaposlitev v pogodbeni rezervi Slovenske vojske smo opravili na podlagi empiričnih podatkov, pridobljenih v okviru raziskave Upravljanje človeških virov $v$ Slovenski vojski: pogodbena rezerva, družine in konec vojaške službe, in sicer med letoma 2007 in 2009. Raziskava je med 10. septembrom 2008 in 19. aprilom 2009 potekala na osmih lokacijah Slovenske vojske po vsej Sloveniji. Vzorca raziskave sta bila oblikovana na podlagi udeležbe pogodbenih pripadnikov rezervne sestave (PPRS) Slovenske vojske na prvih terminih usposabljanja, na katerih navadno sodeluje večina pripadnikov. Raziskavo smo opravili s standardiziranim vprašalnikom, ob prevladujočem zaprtem tipu vprašanj in posameznih odprtih vprašanjih. Prva različica vprašalnika, ki je bil namenjen PPRS ob podpisu pogodbe, je vsebovala 22 spremenljivk, od tega 6 demografskih. Druga različica, ki je bila namenjena PPRS, ki že ima izkušnje z usposabljanjem v pogodbeni rezervi, pa je vsebovala skupaj 15 spremenljivk, od tega 14 demografskih. Anketiranje je ob pomoči Slovenske vojske potekalo skupinsko med usposabljanjem PPRS. Na vprašalnik je odgovorilo 1540 pripadnikov, od tega na prvo različico pri podpisu pogodbe 80, na drugo pa 974 PPRS, ki že imajo izkušnje z usposabljanjem v okviru pogodbene rezerve. V raziskavo je bilo tako vključene 61,6 odstotka vse populacije PPRS.

Analiza je bila narejena s programom SPSS.

Raziskava je pokazala, da o predčasni prekinitvi pogodbe oziroma službe v pogodbeni rezervi Slovenske vojske razmišlja 24 odstotkov anketirancev. Zato ne preseneča podatek, da poleg 5,2 odstotka vprašanih, ki so pogodbo že podaljšali, še kar 64,6 odstotka vseh sodelujočih v anketi z gotovostjo oziroma verjetnostjo načrtuje podaljšanje pogodbe (graf 1).
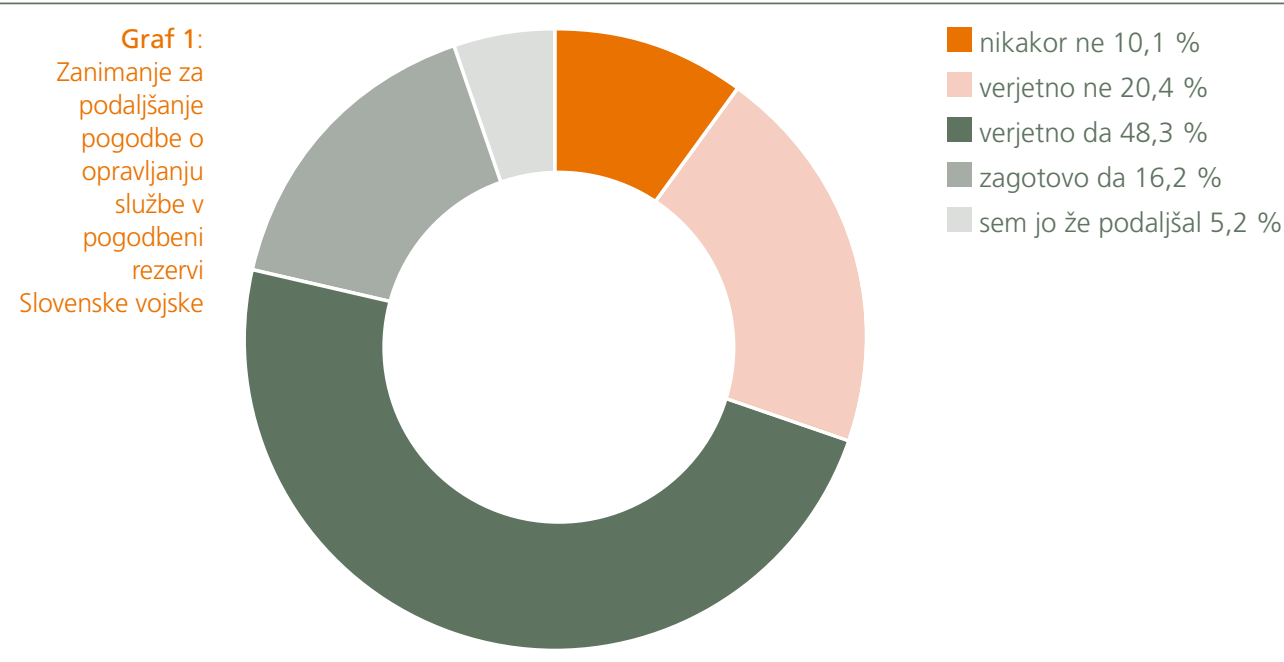
Ker zaposlitev v pogodbeni rezervi hkrati pomeni tako imenovano delno zaposlitev v Slovenski vojski, pri čemer so vezi s sekundarnim delodajalcem bistveno bolj ohlapne kot pri dejanski zaposlitvi, ugotavljamo, da so PPRS precej zainteresirani za zaposlitev v stalni sestavi Slovenske vojske, saj je 47,7 odstotka anketirancev izjavilo, da so srednje, dokaj in zelo zainteresirani za redno vojaško službo.

\subsection{Osebni odnos}

Osebni odnos do zaposlitve v pogodbeni rezervi Slovenske vojske smo merili s spremenljivkama, ki ne kažeta zgolj mnenja o pogodbeni rezervi, temveč tudi o Slovenski vojski. Najprej smo pripadnike pogodbene rezerve spraševali po njihovem zadovoljstvu s sodelovanjem v njej, pri čemer smo za analizo desetstopenjsko lestvico spremenili v tristopenjsko. V prvo stopnjo, s katero so anketiranci izražali najnižjo stopnjo zadovoljstva, so bile združene ocene od 1 do 4 , v drugo stopnjo srednjih vrednosti so bile združene ocene od 5 do 7 in v tretjo, ki odraža najvišjo stopnjo zadovoljstva, so bile združene ocene od 8 do 10. Frekvenčna porazdelitev pokaže slabo petino (18,5 odstotka) manj in približno enak odstotek (19,5 odstotka) zelo zadovoljnih pripadnikov, 41 odstotkov vprašanih je s pogodbeno rezervo srednje zadovoljnih, medtem ko se preostali o svojem zadovoljstvu niso izrekli. T-test (glej preglednico 1$)$ pokaže statistično značilno razliko $(\mathrm{p}=0,000) \mathrm{v}$ stopnji zadovoljstva med tistimi pripadniki PPRS, ki nameravajo podaljšati pogodbo (povprečna vrednost 7,31), in tistimi, ki tega ne nameravajo $(4,93)$.

Med tistimi, ki bodo zagotovo podaljšali pogodbo o zaposlitvi, je kar 59,2 odstotka takšnih, ki so s PPRS zelo zadovoljni, nekaj manj (32,7 odstotka) tistih, ki so srednje zadovoljni, in le 8,2 odstotka nezadovoljnih.

Pripadnike pogodbene rezerve smo spraševali tudi, kako sami cenijo Slovensko vojsko. Lestvico od 1 do 10 smo spremenili po prej opisanem zgledu. Frekvenčna porazdelitev pokaže, da manjši delež (13,3 odstotka) vprašanih malo ceni Slovensko vojsko, slaba četrtina $(23,7$ odstotka) jo zelo ceni, medtem ko je večina $(44,3$ odstotka) svoj odnos opredelila s srednjimi vrednostmi. Obstaja tudi statistično značilna povezava $(\mathrm{p}=0,000)$ med osebno cenitvijo Slovenske vojske in namero podaljšati pogodbo (glej preglednico 1). Med tistimi, ki bodo pogodbo zagotovo podaljšali, je 68,8 odstotka takšnih, ki Slovensko vojsko zelo cenijo, 22,9 odstotka takšnih, ki jo srednje cenijo, in le 8,3 odstotka tistih, ki je ne cenijo. Med tistimi, ki pogodbe zagotovo ne bodo podaljšali, pa je le 6,6 odstotka takšnih, ki Slovensko vojsko zelo cenijo, 46,1 odstotka takšnih, ki jo cenijo srednje, in 47,4 odstotka tistih, ki je ne cenijo. Zanimivo pa je, da je med tistimi, ki so pogodbo že podaljšali, kar 23,3 odstotka takšnih, ki Slovenske vojske ne cenijo, pri čemer pa še vedno prevladujejo tisti, ki jo cenijo srednje (46,7 odstotka) ali zelo (30 odstotkov). Ugotovljeno potrjuje tudi t-test $(\mathrm{p}=0,000)$, saj je povprečna vrednost osebne cenitve Slovenske vojske med tistimi, ki bodo podaljšali pogodbo 7,57 , in med tistimi, ki je ne bodo, le 5,8 . 


\begin{tabular}{|c|c|c|c|c|c|}
\hline \multirow{2}{*}{$\begin{array}{r}\text { Preglednica 1: } \\
\text { T-test: razmerje } \\
\text { med namero } \\
\text { podaljšati }\end{array}$} & & \multicolumn{4}{|c|}{ Nameravate podaljšati pogodbo? } \\
\hline & & & povprečje & $\begin{array}{c}\text { število } \\
\text { anketiranih }\end{array}$ & $\begin{array}{l}\text { standardni } \\
\text { odklon }\end{array}$ \\
\hline $\begin{array}{l}\text { pogodbo v } \\
\text { pogodbeni }\end{array}$ & \multirow{2}{*}{$\begin{array}{l}\text { Kako cenite Slovensko } \\
\text { vojsko? }\end{array}$} & NE & 5,80 & 246 & 2,31 \\
\hline rezervi in & & DA & 7,57 & 519 & 1,82 \\
\hline \multirow{2}{*}{$\begin{array}{r}\text { Osebno cenitvijo } \\
\text { Slovenske vojske } \\
\text { kot delodajalca }\end{array}$} & \multirow{2}{*}{$\begin{array}{l}\text { Kakšno je vaše zadovoljstvo s } \\
\text { pogodbeno rezervo? }\end{array}$} & NE & 4,93 & 245 & 2,43 \\
\hline & & DA & 7,31 & 518 & 1,96 \\
\hline
\end{tabular}

Pričakovanja pripadnikov smo merili s serijo desetih trditev o moči vpliva posameznih dejavnikov na odločitev za vstop v pogodbeno rezervo (Cronbach $\alpha=0,787$ ). Ob vsaki trditvi so anketiranci izrazili moč vpliva na petstopenjski lestvici. ${ }^{5}$ Dejavnike smo združili v skupni faktor, ki izraža pričakovanja pripadnikov. S t-testom ugotavljamo, da je med tistimi, ki dela v pogodbeni rezervi ne nameravajo podaljšati, povprečna vrednost vpliva pričakovanj na zaposlitev v pogodbeni rezervi 2,8; med tistimi, ki pogodbo nameravajo podaljšati, je povprečna vrednost vpliva pričakovanj na zaposlitev v pogodbeni rezervi 3,25; med tistimi, ki so pogodbo v času anketiranja že podaljšali, je povprečna vrednost 3,23. Gre za statistično značilen vpliv pričakovanj na podaljšanje pogodbe $(\mathrm{p}=0,000)$. Največji vpliv na zaposlitev v pogodbeni rezervi je imelo pričakovanje dodatnega zaslužka (povprečna vrednost 3,95). Ugotavljamo tudi, da zgolj v tej kategoriji pričakovanj ni statistično značilnih razlik med tistimi, ki pogodbe ne nameravajo podaljšati, in med tistimi, ki jo nameravajo $(\mathrm{p}=0,281)$. Druga pričakovanja imajo večji vpliv na tiste pripadnike, ki nameravajo pogodbo podaljšati.

Dojemanje koristi smo merili s serijo trditev (Cronbach $\alpha=0,843$ ), ki kažejo stopnjo zadovoljstva $\mathrm{z}$ delom $\mathrm{v}$ pogodbeni rezervi. ${ }^{6}$ Med vsemi dvanajstimi koristmi in ugodnostmi je zadovoljstvo s sovojaki doseglo najvišjo povprečno vrednost $(4,27)$ med pripadniki. S povprečno vrednostjo 3,78 se takoj za njim uvršča zadovoljstvo z nadrejenimi. Skupna povprečna vrednost zadovoljstva z delom v Slovenski vojski je 3,52, kar kaže, da je to rahlo nad povprečjem. S t-testom ugotavljamo statistično značilno povezavo med stopnjo zadovoljstva s pogodbeno rezervo ter namero podaljšati pogodbo $(\mathrm{p}=0,000)$. Povprečna vrednost zadovoljstva med tistimi, ki pogodbe ne nameravajo podaljšati, je 3,23, medtem ko je med tistimi, ki jo nameravajo podaljšati, 3,69.

Zaznava koristi, izhajajočih iz zaposlitve v pogodbeni rezervi Slovenske vojske, je bila merjena tudi neposredno z vprašanjem, ali bi se pripadniki odločili za vstop v

\footnotetext{
5 Vprašanje se glasi: „Ocenite, kolikšen vpliv je imela vsaka od naštetih stvari na vašo odločitev, da se vključite v pogodbeno rezervo. "Anketiranci so se odločali med odgovori: sploh ni vplivala, ni vplivala, delno je vplivala, vplivala je, zelo je vplivala.

6 Vprašanje: „Ocenite vaše zadovoljstvo z enoto služenja v pogodbeni rezervi Slovenske vojske. «Anketiranci so izbirali med odgovori: zelo nezadovoljen, nezadovoljen, niti zadovoljen niti nezadovoljen, zadovoljen in zelo zadovoljen.
} 
pogodbeno rezervo, tudi če za to ne bi dobivali plačila. Večina se je opredelila proti, med njimi 43,2 odstotka $\mathrm{z}$ odgovorom »zagotovo ne« in 36,4 odstotka z »verjetno ne«. Le 15,8 odstotka vprašanih bi bilo pripravljenih v pogodbeni rezervi delovati prostovoljno. Iz tega sledi, da plačilo, v primerjavi z drugimi vzgibi, ki vplivajo na odločitev o delu v vojaški organizaciji, vendarle predstavlja pomemben dejavnik v vrednotnem sistemu posameznika.

\subsection{Normativni pritisk oziroma podpora in deskriptivne norme}

V kontekstu prepovedanih norm oziroma zaznave pomena pogodbene rezerve Slovenske vojske v ožjem družbenem okolju anketiranih pripadnikov smo te spraševali o ugledu pogodbene rezerve $v$ javnosti. ${ }^{7}$ Po mnenju večine vprašanih (43 odstotkov) ima pogodbena rezerva $\mathrm{v}$ slovenski javnosti srednji ugled. Odstotek tistih, ki menijo, da ima majhen ugled, pa je z 41,7 odstotka skoraj izenačen $\mathrm{z}$ odstotkom tistih, ki menijo, da ima srednji ugled. Velik ugled ima le po mnenju 7,2 odstotka javnosti. Statistično značilna $(\mathrm{p}=0,000)$ je povezava med zaznavo ugleda pogodbene rezerve $\mathrm{v}$ javnosti in namero podaljšati pogodbo. Med tistimi, ki menijo, da ima pogodbena rezerva velik ugled, je 83,3 odstotka takšnih, ki pogodbo nameravajo podaljšati, vendar pa je tudi med tistimi, ki dojemajo pogodbeno rezervo kot neugledno, kar 54,5 odstotka takšnih, ki bodo pogodbo kljub tej zaznavi podaljšali. T-test je pokazal tudi statistično značilno $(\mathrm{p}=0,000)$ povezavo med zaznavo ugleda pogodbene rezerve $\mathrm{v}$ javnosti (povprečna vrednost 4,93) in zadovoljstvom $\mathrm{s}$ pogodbeno rezervo (povprečna vrednost 6,49 ).

Merili smo tudi podporo ožjega socialnega okolja pripadnikov. Kot primarno okolje smo definirali partnerje oziroma partnerke, starše, brate/sestre in prijatelje. Zaznavanje njihovega odnosa do vstopa $\mathrm{v}$ pogodbeno rezervo Slovenske vojske smo merili $\mathrm{s}$ serijo trditev (Cronbach $\alpha=0,834) .{ }^{8}$ T-test pokaže, da je raven podpore med tistimi, ki pogodbo nameravajo podaljšati (povprečna vrednost 3,42 ), kot tudi med tistimi, ki je ne nameravajo podaljšati (povprečna vrednost 3,18), približno enaka. Ugotavljamo (glej preglednico 2), da ne prihaja do statistično značilnega vpliva podpore socialnega okolja na namero podaljšati pogodbo $(p=0,787)$. Pri tem je gotovo pomembno dejstvo, da se vsi, z izjemo partnerjev, največkrat niso vmešavali v odločitev o podaljšanju pogodbe. Le partnerji so jih večinoma podpirali (41,1 odstotka).

\footnotetext{
Vprašanje se glasi »Kakšen ugled ima po vašem mnenju v javnosti pogodbena rezerva Slovenske vojske? « Lestvica od 1 do 10 je bila združena $v$ tri kategorije, in sicer prva (ocene od 1 do 4) za najmanjši ugled, druga (ocene od 5 do 7) za srednji ugled in tretja (ocene 8 do 10) za največji ugled.

\& Vprašanje se glasi: »Kako so reagirali našteti, ko ste se odločili za pogodbeno rezervo? « Uporabljena je bila petstopenjska lestvica: nasprotovali so, niso se strinjali, niso se vmešavali, strinjali so se, spodbujali so me, ni relevantno.
} 


\begin{tabular}{r|c|c|c|c|c|} 
Preglednica & \multicolumn{1}{c|}{$\begin{array}{c}\text { Nameravate } \\
\text { 2: Vpliv }\end{array}$} & $\begin{array}{c}\text { Podpora } \\
\text { podaljšati pogodbo? }\end{array}$ & povprečje & število & $\begin{array}{c}\text { standardni } \\
\text { odklon }\end{array}$ \\
\cline { 2 - 5 } $\begin{array}{r}\text { podpore ožjega } \\
\text { socialnega } \\
\text { okolja na } \\
\text { namero }\end{array}$ & $\begin{array}{l}\text { socialnega okolja } \\
\text { ob vstopu v PPRS }\end{array}$ & NE & 3,19 & 169 & 0,62 \\
\cline { 2 - 6 } & & DA & 3,43 & 395 & 0,55 \\
\hline
\end{tabular}

Ugotavljamo, da v javnosti zaznan ugled pogodbene rezerve sicer vpliva na namero o podaljšanju pogodbe, vendar ta vpliv ni odločujoč. Nima pa pomembnega vpliva ožje socialno okolje, kar najverjetneje lahko pripišemo dejstvu, da pripadnike podpira predvsem pri podpisu pogodbe.

Za posameznika ni pomembna le podpora širšega in ožjega družbenega okolja, temveč tudi interes, ki ga pokaže posameznikova socialna mreža, oziroma tako imenovane deskriptivne norme. $Z$ vprašanjem »ali se pripadniki pogodbene rezerve družijo tudi v svojem prostem času«, smo delno ugotavljali sovpadanje interesov. Frekvenčna porazdelitev pokaže, da se večina anketiranih odloča med odgovori redko (40,3 odstotka) in včasih (37,1 odstotka). Za oba skrajna pola se odloča manjši delež vprašanih, in sicer jih 15,1 odstotka trdi, da se nikoli ne družijo, in 6,4 odstotka, da se družijo pogosto.

S serijo vprašanj o tem, kdo iz pripadnikove socialne mreže je zaposlen v Slovenski vojski, smo ugotavljali socialno mrežo, ki si jo posameznik oblikuje znotraj službe v Slovenski vojski. ${ }^{9}$ Frekvenčna porazdelitev pokaže, da je v Slovenski vojski zaposlenih precej prijateljev (26,2 odstotka) in znancev (22,5 odstotka). Delež sorodnikov (ožje in širše družine) je znatno manjši, medtem ko je največ takšnih, ki nimajo nikogar, ki bi bil zaposlen v Slovenski vojski (46,8 odstotka).

Ugotavljamo tudi, da na večino anketiranih pripadnikov pogodbene rezerve delodajalec ${ }^{10}$ ni vplival (52,1 odstotka), na 15,8 odstotka vprašanih je imel majhen vpliv in le na 7,3 odstotka zelo velik. Analiza kaže statistično značilno povezavo ( $\mathrm{p}=$ $0,024)$ med namero podaljšati pogodbo in vplivom delodajalca na odločitev pripadnika o vstopu v pogodbeno rezervo. Zanimivo je, da med nezaposlenimi v primerjavi s tistimi, ki imajo primarno zaposlitev, ni večje odločenosti podaljšati pogodbo $\mathrm{v}$ rezervni sestavi Slovenske vojske. Odstotek nezaposlenih, ki jo nameravajo podaljšati, je 44, in takšnih, ki je ne nameravajo, 40.

\footnotetext{
9 Anketiranci so lahko izbrali več odgovorov ali možnost nihče.

${ }^{10}$ Vprašanje se glasi »Ocenite, kolikšen vpliv je pri vaši odločitvi za služenje v pogodbeni rezervi imel delodajalec.«Anketiranci so izbirali med odgovori zelo velik, velik, srednji, majhen, ni imel vpliva in nisem zaposlen.
} 
Nadalje smo ugotavljali morebitne težave, ki so jih imeli pripadniki z delodajalcem zaradi svojega vstopa v pogodbeno rezervo. Absolutna večina (79,8 odstotka) težav $\mathrm{z}$ delodajalcem ni imela. Ugotovili smo statistično značilno $(\mathrm{p}=0,002)$ povezavo med namero podaljšati pogodbo $\mathrm{v}$ pogodbeni rezervi in težavami $\mathrm{z}$ delodajalcem zaradi zaposlitve $\mathrm{v}$ pogodbeni rezervi. Med pripadniki, ki niso imeli težav z delodajalcem, je le devet odstotkov takšnih, ki zagotovo ne bodo podaljšali pogodbe, medtem ko je med tistimi, ki so imeli težave, takšnih 15,1 odstotka. Prav tako je med tistimi, ki težav niso imeli, 51,2 odstotka takšnih, ki bodo verjetno podaljšali pogodbo, med tistimi, ki so imeli težave, pa jih je le 37,1 odstotka.

\subsection{Samoučinkovitost}

Samooceno pričakovanj in življenjskih ciljev smo merili z vprašanjem o stopnji ambicioznosti. Desetstopenjsko lestvico smo združili v tri kategorije, in sicer ocene od 1 do 4 za izražanje neambicioznosti ter skromnosti, od 5 do 7 za izražanje srednje ambicioznosti ter ocene od 8 do 10 za izražanje močne ambicioznosti. Frekvenčna porazdelitev pokaže prevladujočo srednjo stopnjo ambicioznosti (56 odstotkov), 34 odstotkov se jih je opredelilo za zelo ambiciozne in 9,8 odstotka za skromne. T-test pokaže, da ni statistično značilne povezave med namero podaljšati pogodbo v pogodbeni rezervi Slovenske vojske in ambicioznostjo $(\mathrm{p}=0,117)$. Med tistimi, ki nameravajo podaljšati pogodbo, je povprečna stopnja ambicioznosti 6,7 , med tistimi, ki pogodbe ne nameravajo podaljšati, pa 6,6. S križanji pa smo ugotovili, da je med anketiranci, ki se opredeljujejo kot skromni (21,6 odstotka), vendarle rahlo večji odstotek tistih, ki zagotovo ne nameravajo podaljšati pogodbe. Med srednje ambicioznimi in ambicioznimi je takšnih le slabih deset odstotkov.

Na oceno težavnosti dela $\mathrm{v}$ pogodbeni rezervi vpliva tudi zmožnost njegovega usklajevanja $\mathrm{z}$ družino, prostim časom in primarno zaposlitvijo. ${ }^{11}$ Večina pripadnikov meni, da imajo z usklajevanjem le malo (44,7 odstotka) ali nič (38,8 odstotka) težav. Med namero podaljšati pogodbo $\mathrm{v}$ pogodbeni rezervi in težavnostjo usklajevanja zasebnega življenja in primarne zaposlitve z zaposlitvijo v pogodbeni rezervi obstaja statistično značilna povezava $(\mathrm{p}=0,000)$. Večina tistih, ki imajo z usklajevanjem veliko težav, pogodbe nikakor ( 52,8 odstotka) ali verjetno ( 25 odstotkov) ne bo podaljšala. Večina tistih, ki imajo malo težav (53,8 odstotka) ali oboje usklajujejo brez težav (51,3 odstotka), bo pogodbo verjetno podaljšala (glej preglednico 3).

\footnotetext{
"I Vprašanje se glasi »Kako usklajujete službo, družino, prosti čas in vojaško usposabljanje v pogodbeni rezervi?" Uporabljena je bila štiristopenjska lestvica (od 1 - brez težav do $4-z$ veliko težavami).
} 
Preglednica 3:

Vpliv zmožnosti

usklajevanja

življenja in

primarne

zaposlitve

z namero

podaljšati

pogodbo $v$

Slovenske vojske zasebnega

rezervni sestavi

\begin{tabular}{|c|c|c|c|c|c|c|c|c|}
\hline & \multicolumn{6}{|c|}{$\begin{array}{l}\text { Ali nameravate po njenem preteku pogodbo o opravljanju } \\
\text { službe v pogodbeni rezervi podaljšati? }\end{array}$} \\
\hline & & & $\begin{array}{l}\text { nikakor } \\
\text { ne }\end{array}$ & $\begin{array}{l}\text { verjetno } \\
\text { ne }\end{array}$ & $\begin{array}{l}\text { verjetno } \\
\text { da }\end{array}$ & $\begin{array}{c}\text { zagotovo } \\
\text { da }\end{array}$ & $\begin{array}{l}\text { sem jo že } \\
\text { podaljšal }\end{array}$ & skupaj \\
\hline \multirow{8}{*}{$\begin{array}{c}\text { Kako } \\
\text { usklajujete } \\
\text { službo, } \\
\text { družino, } \\
\text { prosti čas } \\
\text { in vojaško } \\
\text { usposabljanje } \\
\text { v pogodbeni } \\
\text { rezervi? }\end{array}$} & \multirow{2}{*}{$\begin{array}{l}\text { z veliko } \\
\text { težav }\end{array}$} & število & 19 & 9 & 4 & 3 & 1 & 36 \\
\hline & & odstotki & 52,78 & 25,00 & 11,11 & 8,33 & 2,78 & 100,00 \\
\hline & \multirow{2}{*}{$\begin{array}{l}\text { s precej } \\
\text { težav }\end{array}$} & število & 22 & 32 & 28 & 5 & 5 & 92 \\
\hline & & odstotki & 23,91 & 34,78 & 30,43 & 5,43 & 5,43 & 100,00 \\
\hline & \multirow{2}{*}{$\begin{array}{l}\text { z malo } \\
\text { težav }\end{array}$} & število & 28 & 81 & 193 & 36 & 21 & 359 \\
\hline & & odstotki & 7,80 & 22,56 & 53,76 & 10,03 & 5,85 & 100,00 \\
\hline & \multirow{2}{*}{$\begin{array}{l}\text { brez } \\
\text { težav }\end{array}$} & število & 12 & 42 & 163 & 86 & 15 & 318 \\
\hline & & odstotki & 3,77 & 13,21 & 51,26 & 27,04 & 4,72 & 100,00 \\
\hline
\end{tabular}

Merili smo tudi povezavo med obveznostmi, nastalimi $\mathrm{z}$ vstopom $\mathrm{v}$ pogodbeno rezervo, in drugimi sferami življenja pripadnikov. Pripadnike smo spraševali, kolikšen vpliv bo imelo delo v pogodbeni rezervi na njihove družinske obveznosti, partnerja, otroke, prijatelje, prosti čas in primarno zaposlitev. ${ }^{12}$ Določili smo dve skupini. Prvo smo poimenovali primarni socialni krog in vanj uvrstili partnerja, otroke in družinske obveznosti (Cronbach $\alpha=0,918$ ). Drugi, sekundarni socialni krog pa sestavljajo prijatelji, prosti čas in služba (Cronbach $\alpha=0,772)$. Z metodo t-testa $(\mathrm{p}=0,000)$ ugotavljamo, da je povprečen vpliv dela $\mathrm{v}$ pogodbeni rezervi na primarni socialni krog $(2,92)$ večji, kot vpliv na sekundarni socialni krog $(2,76)$. Nadalje ugotavljamo (glej preglednico 4), da obstaja statistično značilna povezava med namero podaljšati pogodbo in vplivom vstopa $\mathrm{v}$ pogodbeno rezervo na primarni $(p=0,008)$ in sekundarni socialni $\operatorname{krog}(p=0,000)$.

\section{Preglednica 4:}

Razmerje med

vplivom dela

$\checkmark$ pogodbeni

rezervi na

pripadnikov

socialni krog in

njegovo namero

podaljšati

pogodbo

\begin{tabular}{|l|c|c|c|c|}
\hline & $\begin{array}{c}\text { Nameravate } \\
\text { podaljšati } \\
\text { pogodbo? }\end{array}$ & Povprečje & Število & $\begin{array}{c}\text { Standardni } \\
\text { odklon }\end{array}$ \\
\hline \multirow{2}{*}{ Primarni socialni krog } & NE & 3,06 & 228 & 1,15 \\
\cline { 2 - 5 } & DA & 2,84 & 477 & 0,99 \\
\hline \multirow{2}{*}{ Sekundarni socialni krog } & NE & 3,01 & 232 & 1,00 \\
\cline { 2 - 5 } & DA & 2,64 & 496 & 0,85 \\
\hline
\end{tabular}

${ }_{12}$ Uporabljena je bila petstopenjska lestvica z odgovori: sploh ne bo vplivalo, ne bo vplivalo, niti bo niti ne bo vplivalo, bo vplivalo, zelo bo vplivalo, ni relevantno. 


\subsection{Oddaljeni dejavniki}

Pripadniki pogodbene rezerve Slovenske vojske imajo večinoma (52,6 odstotka) opravljeno štiriletno strokovno šolo, nekaj manj pa triletno (27,9 odstotka). Manj kot 10 odstotkov je takšnih s končano višjo in visoko strokovno šolo, fakulteto, akademijo, magisterijem ali doktoratom. Večinoma se sami uvrščajo v srednji sloj (68,4 odstotka), 22,3 odstotka v nižji in le 6,4 odstotka v višji sloj. ${ }^{13}$

Med anketiranimi pripadniki pogodbene rezerve prevladuje starostna skupina od 30 do 34 let (glej graf 2). Večina pripadnikov, starih med 21 in 44 leti, odgovarja, da bodo pogodbo najverjetneje podaljšali, medtem ko je starejši od 45 let verjetno ali zagotovo ne bodo. Namera podaljšati pogodbo je statistično značilno povezana $\mathrm{S}$ starostjo $(\mathrm{p}=0,024)$. Ugotavljamo tudi, da v prevladujoči starostni skupini tisti, ki zelo cenijo Slovensko vojsko, večinoma nameravajo podaljšati pogodbo $(68,4$ odstotka), medtem ko večina tistih, ki Slovenske vojske ne ceni, pogodbe ne namerava podaljšati (44,4 odstotka). Med pripadniki, starimi med 25 in 39 leti, obstaja močna statistično značilna povezava med namero podaljšati pogodbo, starostjo in odnosom do Slovenske vojske $(\mathrm{p}=0,000)$.

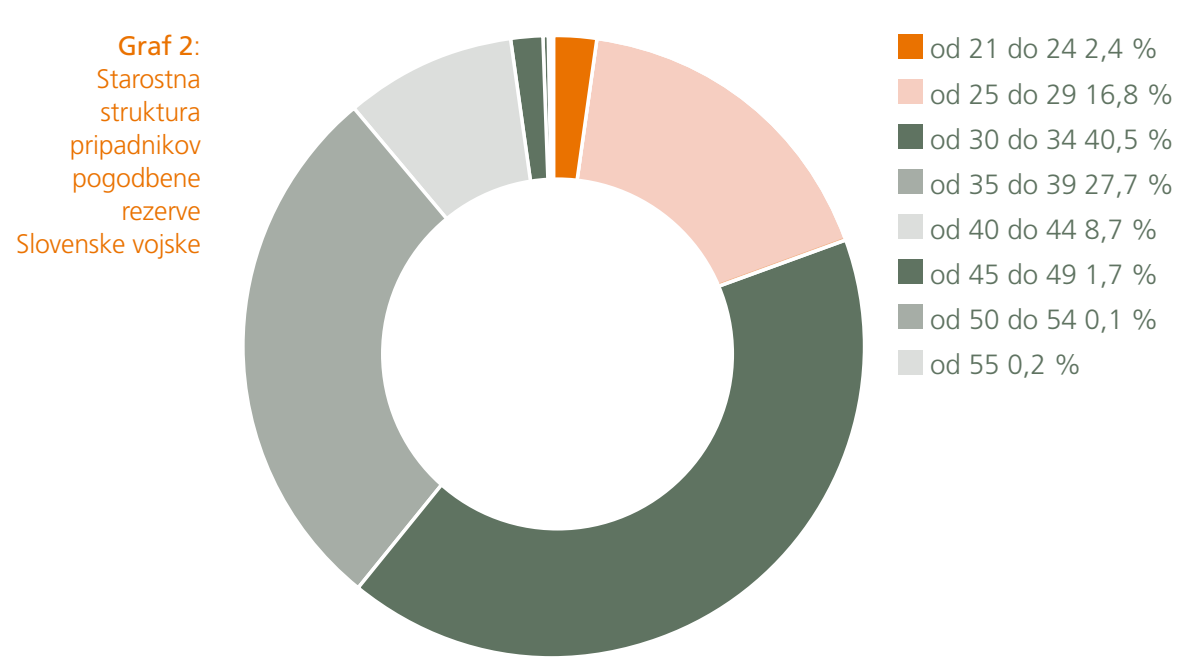

Nadalje ugotavljamo, da večina pripadnikov PPRS spada v Upravo za obrambo Celje (29,7 odstotka). Pri tem obstaja statistično značilna povezava med namero podaljšati pogodbo, odnosom do Slovenske vojske in upravo za obrambo. V upravah Celje, Kranj, Ljubljana, Maribor in Novo mesto je namera podaljšati pogodbo sorazmerna z ugledom Slovenske vojske med pripadniki, medtem ko v Postojni, Murski

\footnotetext{
${ }^{13}$ Za lastno razvrstitev na družbeni lestvici je bila uporabljena lestvica od 1 do 10, ki smo jo za namen te analize združili v tri kategorije, in sicer nižji sloj (ocene od 1 do 4), srednji sloj (ocene od 5 do 7) in višji sloj (ocene od 8 do 10).
} 
Soboti in Novi Gorici prevladuje delež tistih, ki nameravajo podaljšati pogodbo, med obojimi, tako med tistimi, ki cenijo Slovensko vojsko, kot med tistimi, ki je ne.

Večina (53,5 odstotka) pripadnikov živi v kraju, ki je 81 ali več kilometrov oddaljen od kraja usposabljanja. Kljub temu pa analiza kaže, da ni statistično značilne povezave $(\mathrm{p}=0,679)$ med oddaljenostjo od kraja usposabljanja in namero podaljšati pogodbo za delo v pogodbeni rezervi Slovenske vojske.

Raven pripravljenosti pripadnikov, da si z odpovedovanjem izboljšajo svoje zaposlitvene možnosti, smo merili s serijo trditev (Cronbach $\alpha=0,670)$. Pri tem spodnji trditvi tvorita skupino, imenovano »prilagodljivost $"$ (Cronbach $\alpha=0,790)$, in sicer "preseliti se v katerikoli kraj v Sloveniji« in »preseliti se v večje mesto v Sloveniji«. Med tistimi, ki ne nameravajo podaljšati pogodbe, je večina takšnih, ki niso prilagodljivi (62,1 odstotka). Med tistimi, ki pogodbo nameravajo podaljšati, je polovica manj prilagodljivih (51 odstotkov), medtem ko dobra polovica (48,5 odstotka) izraža višjo stopnjo prilagodljivosti in so se pripravljeni tudi preseliti $(\mathrm{p}=0,029)$.

Pripadnike pogodbene rezerve smo spraševali, kako po njihovem mnenju deluje Slovenska vojska. Frekvenčna porazdelitev kaže, da po mnenju večine deluje dobro (47,2 odstotka), nekaj manj je neodločenih (28,9 odstotka), le majhen delež je izbral skrajna odgovora (3,5 odstotka zelo slabo in 6,6 odstotka zelo dobro). Mnenje o ugledu Slovenske vojske je malce slabše, saj večina meni, da ima srednji ugled (53,4 odstotka), po mnenju kar 27,9 odstotka ima majhen ugled in le 18,2 odstotka vprašanih meni, da je njen ugled velik. ${ }^{14} \mathrm{~S}$ t-testom ugotavljamo, da ima po mnenju pripadnikov pogodbene rezerve Slovenska vojska vendarle večji ugled (povprečna ocena 5,63) kot pogodbena rezerva (povprečna ocena 4,94). Nadalje podatki sicer kažejo, da večina pripadnikov namerava podaljšati pogodbo ne glede na mnenje o ugledu Slovenske vojske. Med tistimi, ki menijo, da ima Slovenska vojska majhen ugled, pa je precej več takšnih, ki ne nameravajo podaljšati pogodbe (44,1 odstotka), kot med tistimi, ki menijo, da ima Slovenska vojska velik ugled (15,9 odstotka).

S serijo trditev smo merili tudi zaupanje pripadnikov v institucije. ${ }^{15}$ Ugotavljamo, da daleč največ zaupanja pripadniki namenjajo družini in sorodnikom (povprečna vrednost 3,65). Kar 68,7 odstotka jim zaupa popolnoma in 26,1 odstotka precej. Najmanj zaupanja vredna je po mnenju vprašanih cerkev $(1,79)$, medtem ko zaupanje Slovenski vojski dosega povprečno vrednost 2,73.

Večina pripadnikov meni, da je pred podpisom pogodbe prejela dovolj informacij (58,5 odstotka), medtem ko je bilo 29,4 odstotka nezadovoljnih s količino informacij. Nadalje je večina pripadnikov delno (35,5 odstotka) ali precej (33 odstotkov)

\footnotetext{
${ }^{14}$ Za merjenje ugleda Slovenske vojske je bila uporabljena desetstopenjska lestvica. Za namen te analize smo lestvico združili v tri kategorije, in sicer nizek ugled (1 do 4) srednji ugled (5 do 7) in velik ugled (8 do 10).

${ }_{15}$ Zaupanje smo merili s štiristopenjsko lestvico: sploh nič, le malo, precej, v celoti, ne vem.
} 
zadovoljna z ujemanjem informacij z resničnostjo v enoti. ${ }^{16}$ Obstaja statistično značilna povezava med ujemanjem informacij z resničnostjo v enoti in namero podaljšati pogodbo $(p=0,000)$. Med tistimi, po mnenju katerih se informacije niso popolnoma nič ujemale $\mathrm{z}$ resničnostjo $\mathrm{v}$ enoti, je večina takšnih, ki pogodbe ne bodo podaljšali (68,5 odstotka). Med tistimi, ki menijo, da so se informacije malo ujemale, je mnenje deljeno (50 odstotkov jih ne bo podaljšalo pogodbe, 45 odstotkov jih bo). Med tistimi, ki menijo, da so se informacije ujemale delno (62,4 odstotka), precej (77,8 odstotka) ali popolnoma (84,3 odstotka), pa je večina takšnih, ki nameravajo pogodbo podaljšati.

Sklep V osnovnem ekonomskem modelu, ki proučuje trg vojaške delovne sile, je poklicna izbira opredeljena kot enoobdobni odločevalski problem, v katerem se posameznik o zaposlitvi v oboroženih silah odloči na podlagi razlike med nizom vojaških plačil in nizom plačil za najboljšo civilno alternativno zaposlitev v določenem časovnem obdobju. Vendar pa je kmalu postalo jasno, da se lahko zgodi, čeprav je niz vojaških plačil enak nizu civilnih, da posameznik ni neopredeljen pri izbiri zaposlitve v oboroženih silah, saj obstaja možnost, da se pojavlja neka »nagnjenost do vojaške službe«. Ker so se konec sedemdesetih in v začetku osemdesetih let prejšnjega stoletja v državah, ki so prehajale na poklicno popolnjevanje oboroženih sil, pri zagotavljanju ponudbe poklicne vojaške delovne sile začele pojavljati resne težave, so zagovorniki ekonomskih modelov začeli v raziskave vključevati še številne elemente institucionalnega okolja. Hkrati so vojaški sociologi začeli zagovarjati zamenjavo čisto ekonometričnega proučevanja ponudbe poklicne vojaške delovne sile s socio-ekonomskim proučevanjem, ki z vključitvijo socialnih oziroma neekonomskih vedenjskih spremenljivk, kot so družbeno okolje, zaznavanje pomembnosti vloge oboroženih sil, kohezivnost enote, civilna zavest, družinska tradicija, sprejemanje pravil in odredb, dolžnost, občutek solidarnosti in zadovoljstvo zaradi možnosti napredovanja, daje dodatno konceptualno orodje za proučevanje posameznikovega odločanja za vojaško službo.

Kako pomembno je pri proučevanju posameznikovega odločanja za zaposlitev v oboroženih silah poleg ekonomskih modelov upoštevati tudi socio-psihološki okvir, pa empirično dokazuje tudi analiza stališč pogodbenih pripadnikov do zaposlitve $\mathrm{v}$ rezervni sestavi Slovenske vojske. Pri tem dejstvo, da je bila raziskava opravljena v letih 2008 in 2009, nikakor ne zmanjšuje pomena njenih ugotovitev, saj trenutna gospodarska kriza v ospredje le še bolj očitno postavlja predvsem ekonomske dejavnike vpliva na zanimanje posameznika za zaposlitev v rezervni sestavi, ki so bili kot najbolj ključni zaznani že v tej raziskavi. Čeprav ima že za anketirance v obravnavani raziskavi dodaten zaslužek največji vpliv na odločitev za prvo zaposlitev v pogodbeni rezervi, pa na podaljšanje pogodbe o zaposlitvi v rezervni sestavi Slovenske vojske vplivajo še številni drugi dejavniki. Tako v okviru osebnega odnosa do zaposlitve v rezervni sestavi obstaja statistično značilna povezava med posameznikovo namero

\footnotetext{
${ }^{16}$ Vprašanje se glasi: »Ali se vaše nekdanje predstave o služenju v pogodbeni rezervi, pred podpisom pogodbe, ujemajo z realnostjo v enoti? « Anketiranci so izbirali med odgovori sploh nič, malo, delno, precej, popolnoma in ne vem.
} 
za podaljšanje pogodbe in njegovo cenitvijo Slovenske vojske ter njegovim zadovoljstvom s pogodbeno rezervo. Nezanemarljiva pa z vidika zanimanja za podaljšanje pogodbe o zaposlitvi v rezervni sestavi nista niti vpliv normativnih pritiskov oziroma podpor, ki se kaže s statistično značilno povezanostjo namena podaljšati pogodbo in zaznavo ugleda pogodbene rezerve Slovenske vojske v javnosti, kot tudi ne vpliv deskriptivnih norm, ki se kaže s statistično značilno povezanostjo namena podaljšati pogodbo z vplivom delodajalca na odločitev posameznika o vstopu $\mathrm{v}$ rezervno sestavo in z vplivom težav, ki jih ima pripadnik rezervne sestave z delodajalcem. Posameznikova zaznava samoučinkovitosti statistično značilno učinkuje na interes za podaljšanje pogodbe o zaposlitvi v rezervni sestavi Slovenske vojske prek težavnosti usklajevanja zasebnega življenja in primarne zaposlitve z zaposlitvijo v pogodbeni rezervi. Med vplivom oddaljenih dejavnikov pa moramo opozoriti predvsem na statistično značilnost zanimanja za podaljšanje pogodbe o zaposlitvi v rezervni sestavi Slovenske vojske s starostjo anketirancev in njihovo zaznavo ujemanja predhodnih informacij $\mathrm{z}$ realnostjo zaposlitve $\mathrm{v}$ pogodbeni rezervi.

Če bo Slovenska vojska tudi v prihodnje želela imeti popolnjeno in predvsem kakovostno pogodbeno rezervo, bo morala poleg sorazmerno dobrega dodatnega zaslužka in ugleda $\mathrm{v}$ javnosti poskrbeti tudi za: 1) jasno opredelitev namena pogodbene rezerve; 2) večjo povezanost pogodbene rezerve s stalno sestavo; 3) več pozornosti in ugodnosti družinam PPRS (že vključenih ali tistih, ki razmišljajo o tem); 4) boljše sodelovanje s primarnimi delodajalci pripadnikov; 5) ujemanje informacij o zaposlitvi v pogodbeni rezervi (pričakovanj potencialnih pripadnikov pogodbene rezerve SV) z realnostjo.

1. Altman, Stuart H., in R. J. Barro, 1971. Officer Supply-TheImpact of Pay, the Draft and the Vietnam War. American Economic Review. 61 - 4, str. 649-664.

2. Altman, Stuart H., in Alan E. Fechter, 1967. Military Manpower Procurement, The Supply of Military Personnel in the Absence of a Draft. American Economic Review. 57 - 2, str. 19-31.

3. Ajzen, I., 1991. The Theory of Planned Behaviour. Organizational Behaviour and Human Decision Process. 50, str. 179-221.

4. Ajzen, I., in M. Fishbine, 1980. Understanding Attitudes and Predicting Social Behaviour. Englewood Cliffs: Prentice-Hall.

5. Bakken, T., 2002. The Role of Human Agency in the Creation of Normative Influences within Individuals and Groups. Journal of Human Behavior in the Social Environment. 5, str. 89-104.

6. Bandura, A., 1977. Self-Efficacy: Toward a Unifying Theory of Behavioral Change. Psychological Review. 84, str. 191-215.

7. Bandura, A., 1994. Social Cognitive Theory and Exercise of Control over HIV Infection. V R. J. DiClemente in J. L. Peterson, ur. Preventing AIDS: Theories and Methods of Behavioral Interventions. New York: Plenum Press, 1994, str. 26-29.

8. Becker, M. H., 1974. The Health Belief Model and Personal Health Behaviour. Health Education Monographs. 2, str. 324-508.

9. Berner, K., in T. Daula, 1993. Recruiting Goals, Regime Shifts and Supply of Labour to the Army. Defence Economics. 4 - 4, str. 315-328. 
10. Brinkerhoff, J. R., in D.W. Grissmer, 1986. The Reserve Forces in an All-Volunteer Environment. V Bowman, W., Little, R, in Sicilia, G.T., ur. The All-Volunteer Force After a Decade, Washington: Pergamon-Brassey, 1986, str. 206-229.

11. Buddin, R., 1993. Recruiting for Joint Active/Reserve Tours. Defence Economics. 4-1, str. $15-32$.

12. Burrightetal, Burke K., David W. Grissmer, in Zahava D. Doering, 1978. A model of Reenlistment Decisions of Army National Guardsmen. Santa Monica: RAND Corporation.

13. Cialdini, R., 2003. Craftin Normative Messages to Protect the Environment. Current Directions in Psychological Science. 12, str. 105-109.

14. Daula, Thomas V., in D. Alton Smith, 1985. Estimating Enlistment Models for the U.S. Army. V R.G. Ehrenberg, ur. Research in Labour Economics. Greenwich: JAI Press, Inc., 1985, str. 261310.

15. Fishbein, M., 2000. The role of theory in HIV prevention. AIDS Care. 12 - 3, str. 273-278.

16. Fishbein, M., in I. Ajzen, 1975.Belief, Attitude, Intention and Behavior: An Introduction to the Theory and Research. Reading: Addison-Wesly.

17. Fishbein, M., S. E. Middlestadt, in P. J. Hitchcock, 1991. Using Information to Change Sexually Transmitted Disease-Related Behaviors: An Analysis Based on the Theory of Reasoned Action. V.J. N. Wasserheit, S. O. Aral, in K. K. Holmes, ur. Research Issues in Human Behavior and Sexually Transmitted Diseases in the AIDS Era. Washington: American Society for Microbiology, 1991, str. 243-57.

18. Fisher, Anthony C., 1969. The Cost of the Draft and the Cost of Ending the Draft. The American Economic Review. 59 - 3, str. 239-54.

19. Gilroy, Curtis I., Robert L. Phillips, in John D. Blair, 1990. The All-Volunteer Army: Fifteen Years Later. Armed Forces and Society. 16-3, str. 329-350.

20. Hastie, R., in R. Dawes, 2001. Rational Choice in an Uncertain World. Thousand Oaks: Sage.

21. Hosek, James R, John Antel, in Cristina E. Peterson, 1989. Who Stays; Who Leaves? Attrition Among Firs-Term Enlistees. Armed Forces and Society. 15 - 3, str. 378-398.

22. Kennedy, Garvin, 1975. The Economics of Defence. London: Faber\&Faber.

23. Mehay, Stephen L., 1991. An analysis of migration in the U.S. Army Reserve. Monterey: Naval Postgraduate School.

24. Obramboslovni raziskovalni center, 2009. Upravljanje človeških virov v Slovenski vojski: pogodbena rezerva - baza podatkov. Ljubljana: FDV.

25. Oi, Walter Y., 1967. The Economic Costs of the Draft. The American Economic Review. $57-2$, str. 39-62.

26. Polich, M., J. Dertouzos, in J. Press, 1986. The Enlistment bonus experiment. RAND Report R-3353-FMP. Santa Monica: RAND.

27. Rosenstock, I. M., V. J. Strecher, in M. H. Becker, 1994. The Health Belief Model and HIV Risk Behavior Change. VR. J. Di Clemente in J. L. Peterson, ur. Preventing AIDS: Theories and Methods of Behavioral Interventions. New York: Plenum Press, 1994, str.5-24.

28. Rostker, D. Bernard, in Robert Shishko, 1976. The Air Force Reserve and the Economics of Secundary Labour Market Participation, R-1254 PR. Santa Monica: RAND Corporation.

29. Sackett, P., in A. Mavor, 2004. Evaluating Military Advertising and Recruiting: Theory and Methodology. Washington: National Academies Press.

30. Schwartz, Barry, Andrew Ward, John Monterosso, Sonja Lyubomirsky, Katherine White, in Darrin R.Lehman, 2002. Maximizing versus satisficing: Happiness is a matter of choice. Journal of Personality and Social Psychology. 83 - 5, str. 1178-1197.

31. Sendler, Todd, in Keith Hartley, 1992. The Economics of Defence. Cambridge: Cambridge University Press.

32. Thomas, George, in Kathryn Kocher, 1993. Gender Differences in Turn over Among U.S. Anny Reservists. Defence Economics. 4, str. 339-352. 